\title{
Immunological Characterization in Malaria Patients with and without the Sickle-Cell Trait
}

\author{
Howaida A. Nafady ${ }^{1,2}$, Amany M. Eida ${ }^{2,3}$, Omima M. Eida ${ }^{2,3}$ \\ ${ }^{1}$ Department of Internal Medicine, Faculties of Medicine, Assuit University, Assiut, Egypt \\ 2Jazan University, Jazan, KSA \\ ${ }^{3}$ Department Parasitology, Faculty of Medicine, Suez Canal University, Ismaïlia, Egypt \\ Email: howaidanafady@yahoo.com
}

Received 24 June 2014; revised 24 July 2014; accepted 10 August 2014

Copyright (C) 2014 by authors and Scientific Research Publishing Inc.

This work is licensed under the Creative Commons Attribution International License (CC BY). http://creativecommons.org/licenses/by/4.0/

(c) (i) Open Access

\section{Abstract}

Background: Malaria is one of the main causes of mortality in tropical zone. Specific immune responses are induced by parasite, including the release of cytokines from peripheral blood mononuclear cells. Sickle cell trait confers a high degree of resistance to severe and complicated malaria. The present study aims to assess immunological response of $P$. falciparum infection by measuring of total IgG level and IL-6, IL-12 \& IL-18 levels for P. falciparum among Saudi Arabian patients with and without sickle-cell trait. Patients and Methods: Thirty patients who had clinical suspicion of malaria and sickle-cell trait attending Jazan general hospital in KSA were included in the study. Malaria patients with sickle-cell trait will be matched with a control (thirty patients diagnosed to have malaria but without sickle-cell trait). Diagnosis of malaria was done by Immunochromatography strip and blood film. Diagnosis of Sickle-cell trait was done by hemoglobin electrophoresis assessment of total IgG titre and Interleukin 6, 12, 18 levels using ELIZA. Results: Cytokines and IgG in uncomplicated clinical malaria $(n=22)$ and severe malaria $(n=7)$ were IL6 $(83.1 \mathrm{pg} / \mathrm{mL})$ versus $(75.2 \mathrm{pg} / \mathrm{mL}), \operatorname{IL12}(19.4 \mathrm{pg} / \mathrm{mL})$ versus $(16.3 \mathrm{pg} / \mathrm{mL}), \operatorname{IL18}(22.45 \mathrm{pg} / \mathrm{mL})$ versus $(24.2 \mathrm{pg} / \mathrm{mL})$ and IgG (13.3 SD) versus (4.5 SD). Differences in the IL6, IL12 and IgG were statistically significant ( $p$ value $>0.02,>0.004 \&>0.002$ respectively). Among malaria patients with sickle cell trait, Cytokines and IgG in asymptomatic $(n=19)$ and uncomplicated clinical malaria $(n$ = 11) were IL6 $(88.9 \mathrm{pg} / \mathrm{mL})$ versus $(79.2 \mathrm{pg} / \mathrm{mL})$, IL12 $(24 \mathrm{pg} / \mathrm{mL})$ versus $(22.9 \mathrm{pg} / \mathrm{mL})$, IL18 $(24.2 \mathrm{pg} / \mathrm{mL})$ versus $(31.2 \mathrm{pg} / \mathrm{mL})$ and IgG (27 SD) versus (7.35 SD). Differences in IgG were statistically significant ( $p$ value $\geq \mathbf{0 . 0 0 3}$ ). Serum IL6 levels were higher in patients with uncomplicated clinical malaria without sickle cell trait (median $83.1 \pm 5.1 \mathrm{pg} / \mathrm{mL}$ ) than in patients with uncomplicated clinical malaria with sickle cell trait (medians $79.2 \pm 4.5 \mathrm{pg} / \mathrm{mL}$ ). This difference was statistically significant $(p$ value $=\mathbf{0 . 0 0 3}$ ). Serum IgG levels were higher in patients with uncomplicated clinical malaria without sickle cell trait (median $13.3 \pm 10.84$ ) than in patients with uncomplicated clinical malaria with sickle cell trait (medians $7.35 \pm 2.95$ ) while in asymptomatic malaria 
and severe malaria, medians $(27 \pm 11.13$ versus $4.5 \pm 2.75)$. This difference was statistically highly significant ( $p$ value $=0.0009$ ). Conclusion: Malaria protection by HbAS involves the enhancement of not only innate but also of acquired immunity to the parasite. Cytokins (IL6, IL12) and IgG play an important role in protection against severe malaria. The presence of $\mathrm{HbAS}$ is associated with increased acquired immunity to malaria. Further work will be done to work out how this change in immunity occurs but treatment of anyone with malaria, whatever their sickle cell status, is essential.

\section{Keywords}

\section{Malaria, Sickle Cell Trait, IL-6, IL-12, IL-18 and IgG}

\section{Introduction}

Malaria is one of the main causes of mortality in tropical zone. Severe anemia and cerebral malaria is the main cause of morbidity and mortality [1]. Each year malaria accounts for an estimated 247 million new cases, which result in approximately 881,000 deaths, 91\% of which occur in Africa and 85\% being in children under 5 years of age [2]. In areas of high $P$. falciparum transmission, malaria infection manifests primarily as severe anemia, high density parasitemia, respiratory distress, acute renal failure, hypoglycemia and cerebral malaria [3]. P. falciparum infection begins with an asymptomatic extraerythrocytic hepatic phase. The intra-erythrocytic phase occurs when merozoites attack circulating erythrocytes then all symptoms and pathology of malaria begin [4] The outcome of infection depends interaction between $P$. falciparium parasite and human including a delicate balance between appropriate and inappropriate induction of mediators [5]. A specific immune response is induced by parasite, including the release of cytokines from peripheral blood mononuclear cells [6] [7] which lead to activation of neutrophils, macrophages, T cells and natural killer (NK) cells [8] The inflammatory response requires the production of inflammatory cytokines, such as interleukins as IL-6 [9], interferon (IFN) [10] and IL-18 which is a product mainly of activated monocytes/macrophages [11] [12]. They act as a chemo attractant factor [13]. This inflammatory response causes a considerable tissue damage, and the activation of phagocytes to kill and remove both intracellular and extracellular parasites [10]. Activated macrophages lead to early activation of T, B lymphocytes and NK cells by IL-12, causing more production of $\gamma$-IFN [14]. IL-18 and IL-12 are considered the main factors that control the response of $\gamma$-IFN and TNF- $\partial$ from peripheral blood mononuclear cells respectively [11] [15]. There is a strong relation between these 2 cytokines and clinical outcomes of malaria [16].

Red blood cell polymorphisms are frequently in zone where malaria is endemic so, some of these polymorphisms may give a relative advantage for survival [17]. The sickle cell trait (HbAS), comprising heterozygous carriage of hemoglobin $(\mathrm{Hb}) \mathrm{S}$, the result of a valine substitution for glutamic acid at position 6 of the hemoglobin $\mathrm{b}$ chain. HbAS has also been reported to protect against high parasitemia and morbidity of $P$. falciparum malaria [18] [19]. Mechanisms of protection made by HbAS, include poorer parasite invasion and growth rates in HbAS erythrocytes due to accelerated Sickling of parasite-infected HbAS erythrocytes, and accelerated phagocytosis of infected HbAS erythrocytes [20]-[22]. However the contribution of all of these in vivo is not known. "Variant surface antigens" (VSAs) of P. falciparum might play a role in the physiopathology of disease by adhesive interactions with different endothelial receptors of host [23] IgG antibodies directed to VSAs which might play a role in the protection of HbAS against parasite [24].

The present study aims to assess immunological response of $P$. falciparum infection by measuring of total IgG level and IL-6, IL-12 \& IL-18 level for P. falciparum among Saudi Arabian patients with and without Sickle-cell disease.

\section{Patients and Methods}

\subsection{Patients}

The study was conducted on 60 patients (20 - 45 years old) admitted to jazan general hospital in the period between March 2013 to February 2014 in the internal medicine department complaining of unexplained fever and 
diagnosed malaria, according to the clinical types of malaria the patients were classified into asymptomatic, uncomplicated and severe cases. Thirty malaria patients with Sickle-cell trait were included in the study. Malaria patients with the Sickle-cell trait was be matched with a control (Thirty patients diagnosed to have malaria but without Sickle-cell disease) to study the different associated factors.

\subsection{Samples}

The Blood samples were collected during a three-month period from January to March, a period coinciding with maximum malaria transmission in the endemic area. Blood samples were divided into three parts; first part was used for diagnosis of malaria by Immunochromatographic strip test then staining of blood film and; second part was used for diagnosis of Sickle-cell anemia and third part was stored as serum in $-20^{\circ} \mathrm{C}$ for assessment of total IgG titre and Interluekin 6, 12, 18 levels using ELIZA.

Screening for malaria parasites was done using Immunochromatographic stip test (ICT) according to [25] suspected cases of Malaria were confirmed by blood smears. Blood smears were stained with $1 \%$ Giemsa in PBS (pH 7.0) and examined by microscopy for malaria parasites as shown in Figure 1. Blood film was considered negative if no parasites seen in 300 oil immersion fields on thin blood film. Parasite count was done according to [26] by determining of the number of parasitized red blood cells in 10,000 red blood cells. The approximate level of parasitemia (parasites no/microliter) was calculated; it is assumed that $1 \mu \mathrm{l}$ of blood contained $5 \times 10^{6}$ erythrocytes when the patient's baseline erythrocyte count not available. According to WHO criteria, Malaria is classified as following: Uncomplicated clinical malaria defined as any parasitemia with fever (temperature more than $37^{\circ} \mathrm{C}$ or reported fever) or fever with a parasite density of $>2500$ parasites/microliter [27]. Sever malaria defined as criteria as malaria that present with life-threatening conditions (coma, severe anemia, hypoglycemia, shock or convulsions); hemoglobin level of $5.0 \mathrm{~g} / \mathrm{dL}$ in association with a parasite density of $>10,000$ parasites/microliter [28]; asymptomatic malaria defined as positive blood film or immunochromatography test with absence of symptoms. Parasite rate among patients infected by plasmodium with and without the Sickle- cell disease were assessed.

Sickle-cell trait was diagnosed by complete blood count (CBC) by coulter and peripheral blood film according to Herrick J et al., Hemoglobin types A, F, S were determined by standard hemoglobin electrophoresis according to [29]), Sickle cell test according to [30].

Total IgG titre against plasmodium were assessed by ELIZA using commercial available kits according to the manufacturer's protocol (Abcam, UK). Briefly, The 96 well malaria coated plate were used. Ten $\mu \mathrm{L}$ sample was added to $990 \mu \mathrm{L}$ IgG Sample Diluent to obtain a 1:100 dilution and mixed gently and thoroughly. One hundred $\mu \mathrm{L}$ of controls or diluted samples were added into appropriate wells. All standards, controls and samples were assed in duplicate and $100 \mu \mathrm{L}$ of Malaria anti-IgG horseradish peroxidase-conjugate was added and Incubated for 30 minutes at room temperature. Finally, $100 \mu \mathrm{L}$ TMB Substrate Solution were added to all wells and incubated for 15 minutes at room temperature in the dark then $100 \mu \mathrm{L}$ Stop Solution into all wells in the same order and at the same rate as for the TMB Substrate Solution. The absorbance of the specimen at $450 \mathrm{~nm}$ was measured within 30 minutes of addition of the Stop Solution. Cut-off was 10 Standard Units and Samples are considered negative $<9$ Standard Units and Positive $>11$ Standard Units.

The determination of IL-18, IL-12 and IL-6 were measured by an enzyme-linked immunosorbent assay using commercial available kits according to the manufacturer's protocol (Abcam, UK respectively). The mean absorbance for each set of duplicate standards, controls and samples were calculated and subtracted the average zero standard optical density. The data analysis was carried out by generating a linear standard curve according to the manufacturer's instructions. The lower limits of detection of the assay in malaria patients are $6.3 \mathrm{pg} / \mathrm{ml}$ and $7 \mathrm{pg} / \mathrm{ml}$ for IL-18 and IL-12, respectively. The upper limits in the healthy subjects are $4.8 \mathrm{pg} / \mathrm{ml}$ and 5.2 $\mathrm{pg} / \mathrm{ml}$ for IL-18 and IL-12, respectively. The minimum detectable dose of IL-12 is less than $0.75 \mathrm{pg} / \mathrm{mL}$ and minimum detectable dose of IL-6 was found to be less than $0.81 \mathrm{pg} / \mathrm{mL}$.

\subsection{Statistical Analysis}

Student's two-tailed $t$-test and is used comparing the mean concentrations of cytokins and Total IgG in both groups. For $t$-test, $\mathrm{p}$ value $<0.05$ is considered statistically significant. All calculations are performed using (Excell). 


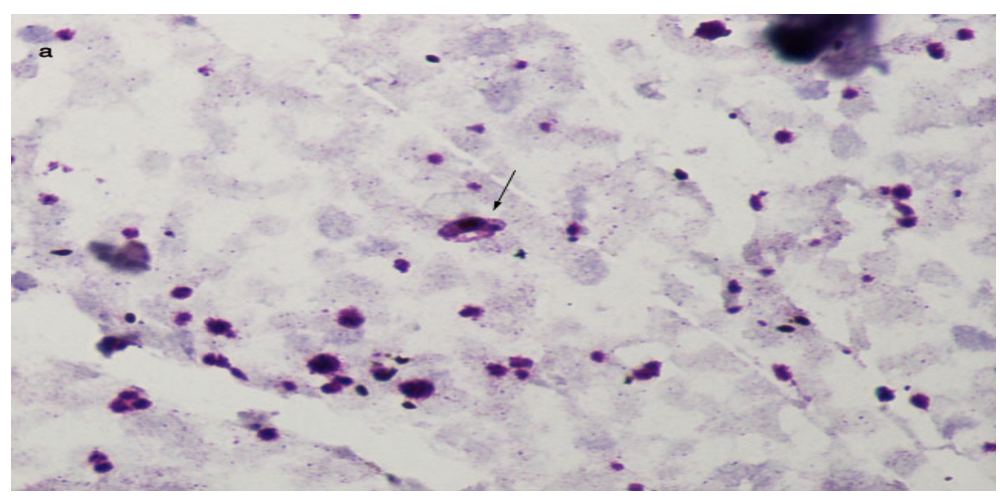

(a)

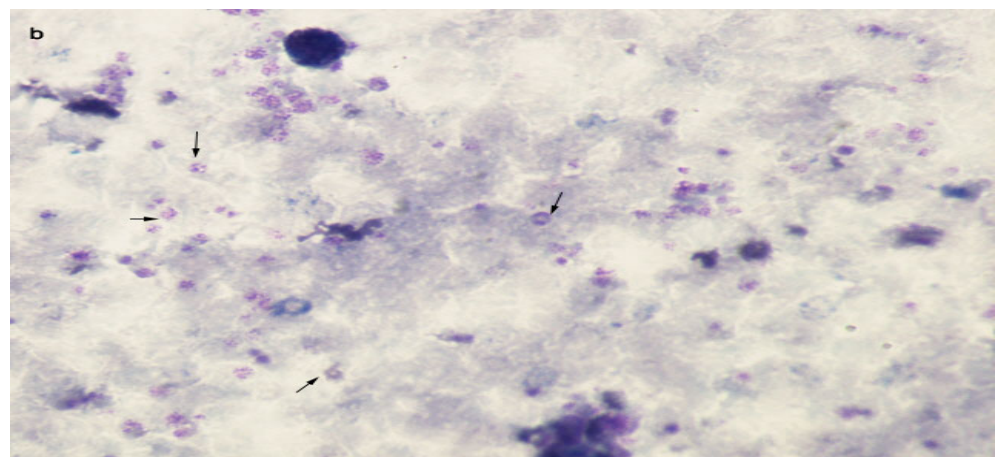

(b)

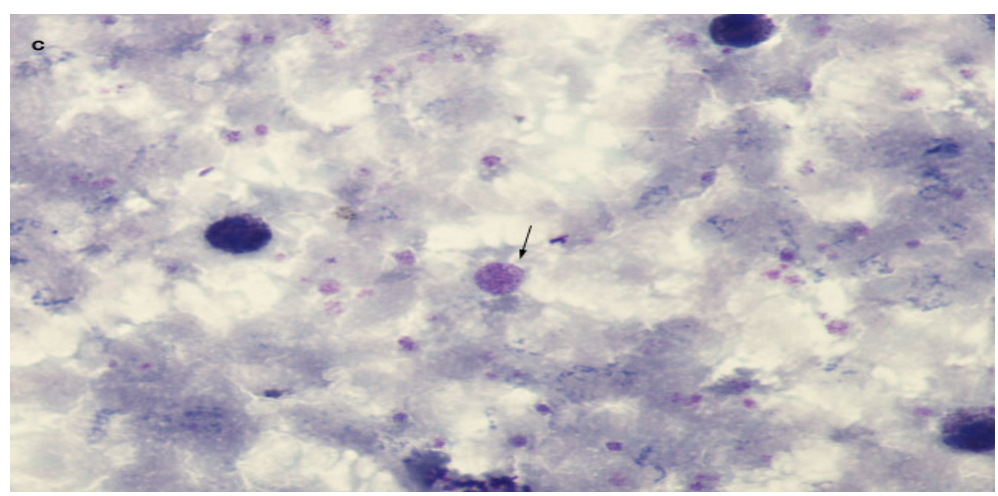

(c)

Figure 1. Blood smear showing (a) (P. falciparum gametocyte), (b) (P. falciparum ring stage), and (c) (P. falciparum in a thick blood film).

\subsection{Ethical Considerations}

The study was reviewed and ethically approved by the Ethical Committee of University of Jazan. Samples will be collected following written informed consent from patients. All patients were treated and followed by clinician.

\section{Results}

\subsection{Participant Characteristics}

The malaria patients without sickle cell trait (30), 20 of them (66.6\%) were in age group (20 - $30 \mathrm{y}$ ) and 10 patients (33.4\%) were in age group (30 - $45 \mathrm{y}$. Thirteen patients were female and 17 were male $(43.3 \%$ and 56.7\% respectively). One patient was asymptomatic, 22 were presented with uncomplicated clinical malaria and 7 were 
presented with severe malaria (3.3\%, $73.3 \%$ and $23.3 \%$ respectively), while Of the 30 malaria patients with sickle cell trait, 22 patients (73.3\%) were in age group (20 - 30 y) and 8 patients (26.3) were in age group (30 45 y). Twelve patients were female and 18 were male ( $40 \%$ and $60 \%$ respectively). Nineteen patients were asymptomatic, 11 were presented with uncomplicated clinical malaria (63.3\% and $36.7 \%$ respectively) while there is no cases presented with sever malaria (Table 1).

\subsection{Immune Parameters and Presence of Sickle Cell Trait}

Among malaria patients without sickle cell trait, Cytokines and IgG in uncomplicated clinical malaria $(\mathrm{n}=22)$ and severe malaria $(\mathrm{n}=7)$ were IL6 $(83.1 \mathrm{pg} / \mathrm{mL})$ versus $(75.2 \mathrm{pg} / \mathrm{mL})$, IL12 $(19.4 \mathrm{pg} / \mathrm{mL})$ versus $(16.3 \mathrm{pg} / \mathrm{mL})$, IL18 $(22.45 \mathrm{pg} / \mathrm{mL})$ versus $(24.2 \mathrm{pg} / \mathrm{mL})$ and IgG (13.3 SD) versus (4.5 SD). Of these results, differences in the IL6, IL12 and IgG were statistically significance (p value $>0.02,>0.004 \&>0.002$ respectively) (Table 2, Figure 2, Figure 3 and Figure 5).

Among malaria patients with sickle cell trait, Cytokines and IgG in asymptomatic $(\mathrm{n}=19)$ and uncomplicated clinical malaria $(\mathrm{n}=11)$ were IL6 $(88.9 \mathrm{pg} / \mathrm{mL})$ versus $(79.2 \mathrm{pg} / \mathrm{mL})$, IL12 24 pg/versus $22.9 \mathrm{pg} / \mathrm{mL}$, IL18 24.2 $\mathrm{pg} / \mathrm{mL}$ versus $31.2 \mathrm{pg} / \mathrm{mL}$ and IgG $27 \mathrm{SD}$ versus $7.35 \mathrm{SD}$. Of these results, differences in IgG were statistically significant (p value $\geq 0.003$ ) (Table 2, Figures 2-5).

Serum IL6 levels were higher in patients with uncomplicated clinical malaria without sickle cell trait (median $83.1 \pm 5.1 \mathrm{pg} / \mathrm{mL}$ ) than in patients with uncomplicated clinical malaria with sickle cell trait (medians $79.2 \pm 4.5$ $\mathrm{pg} / \mathrm{mL}$ ) This differences was statistically significant (p value $=0.003$ ) (Figure $2 \&$ Table 2 ).

Serum IgG levels were higher in patients with uncomplicated clinical malaria without sickle cell trait (median

Table 1. Characteristics of patients included in the study.

\begin{tabular}{|c|c|c|c|}
\hline \multirow[t]{2}{*}{ Characteristic } & \multicolumn{2}{|c|}{$\begin{array}{l}\text { No. }(\%) \\
(60)\end{array}$} & \multirow[b]{2}{*}{$\mathrm{p}$} \\
\hline & Without Sickle Cell Trait (30) & Sickle Cell Trait (30) & \\
\hline $\begin{array}{l}\text { Age (y): } \\
(20-30) \\
(30-45 y)\end{array}$ & $\begin{array}{l}20(66.6 \%) \\
10(33.4 \%)\end{array}$ & $\begin{array}{c}22(73.3 \%) \\
8(26.3)\end{array}$ & 0.2 \\
\hline \multicolumn{4}{|l|}{ NO \%: } \\
\hline Female & $13(43.3 \%)$ & $12(40 \%)$ & 0.01 \\
\hline Male & 17 (56.7\%) & $18(60 \%)$ & \\
\hline \multicolumn{4}{|l|}{ Hemoglobin: } \\
\hline HS & $0 \%$ & $40 \%$ & \\
\hline AA & $100 \%$ & $60 \%$ & \\
\hline Hgb level (g/dl) & $13.3(3.6)$ & $9(1.3)$ & 0.02 \\
\hline White blood cell count $\times 109$ & $7.5(2.8)$ & $13(3.8)$ & 0.001 \\
\hline Temperature & 37.5 & 37.5 & 0.364 \\
\hline Parasite density (MPS/L) & $18.98(39.22)$ & $14.95(44.24)$ & \\
\hline $\begin{array}{l}\text { No of patients with } \\
\text { High density parasitemia }\end{array}$ & $7(23 \%)$ & 0 & 0.2 \\
\hline \multicolumn{4}{|l|}{ Blood group: } \\
\hline $\mathrm{O}$ & $5(1.6 \%)$ & $5(1.6 \%)$ & \multirow{4}{*}{1} \\
\hline A & $10(33.4 \%)$ & $10(33.4 \%)$ & \\
\hline $\mathrm{AB}$ & $10(33.4 \%)$ & $10(33.4 \%)$ & \\
\hline B & $5(1.6 \%)$ & $5(1.6 \%)$ & \\
\hline \multicolumn{4}{|l|}{ Malaria } \\
\hline Asymptomatic malaria & $1(3.3 \%)$ & 19 (63.3\%) & \\
\hline Uncomplicated clinical malaria & $22(73.3 \%)$ & $11(36.7 \%)$ & 0.5 \\
\hline Severe malaria & $7(23.3 \%)$ & 0 & \\
\hline
\end{tabular}


Table 2. Analysis of IL 6, IL 12, IL 18 and total IgG among malaria patients with and without sickle cell trait.

\begin{tabular}{|c|c|c|c|c|c|}
\hline Patients & No. \% & $\begin{array}{c}\mathrm{IL} 6 \\
\mathrm{pg} / \mathrm{ml} \\
\text { Mean } \pm \mathrm{SD}\end{array}$ & $\begin{array}{c}\text { Il } 12 \\
\mathrm{pg} / \mathrm{ml} \\
\text { Mean } \pm \mathrm{SD}\end{array}$ & $\begin{array}{c}\text { IL } 18 \\
\mathrm{pg} / \mathrm{ml} \\
\text { Mean } \pm \mathrm{SD}\end{array}$ & $\begin{array}{c}\text { Total IgG } \\
\text { SD } \\
\text { Mean } \pm \text { SD }\end{array}$ \\
\hline \multicolumn{6}{|c|}{ Without Sickle Cell Trait } \\
\hline Asymptomatic malaria & $1(3.3 \%)$ & 84 & 24 & 25 & 14 \\
\hline $\begin{array}{l}\text { Uncomplicated } \\
\text { clinical malaria }\end{array}$ & $22(73.3 \%)$ & $83.1 \pm 5.1^{\mathrm{a}}$ & $19.45 \pm 3.5^{c}$ & $22.45 \pm 3.8^{\mathrm{e}}$ & $13.3 \pm 10.84^{g}$ \\
\hline Severe malaria & 7 (23.3\%) & $75.2 \pm 3.4^{\mathrm{a}}$ & $16.3 \pm 1.3^{\mathrm{c}}$ & $24.2 \pm 1.4^{\mathrm{e}}$ & $4.5 \pm 2.75^{\mathrm{g}}$ \\
\hline \multicolumn{6}{|c|}{ With Sickle Cell Trait } \\
\hline Asymptomatic malaria & $19(63.3 \%)$ & $88.9 \pm 2.9^{b}$ & $24 \pm 1.8^{\mathrm{d}}$ & $24.2 \pm \_2 .^{f}$ & $27 \pm 11.13^{\mathrm{h}}$ \\
\hline $\begin{array}{l}\text { Uncomplicated } \\
\text { clinical malaria }\end{array}$ & $11(36.7 \%)$ & $79.2 \pm 4.5^{\mathrm{b}}$ & $22.9 \pm 2.4^{\mathrm{d}}$ & $31.2 \pm 1.5^{f}$ & $7.35 \pm 2.95^{\mathrm{h}}$ \\
\hline Severe malaria & - & - & - & - & - \\
\hline
\end{tabular}

${ }^{\mathrm{a}} \mathrm{Il} 6$ \{p value $=0.02{ }^{\mathrm{b}} \mathrm{Il} 6 \mathrm{p}$ value $=3.3$ (between both groups IL $6 \mathrm{p}$ value $=0.003$ ) $\} .{ }^{\mathrm{c}} \mathrm{Il} 12$ \{p value $=0.004 ;{ }^{\mathrm{d}} \mathrm{Il} 12 \mathrm{p}$ value $=5.77$ (between both groups IL $12 \mathrm{p}$ value $=0.1)\}$. ${ }^{\mathrm{e}} \mathrm{IL} 18$ p value $=2.6 ;{ }^{\mathrm{f}} \mathrm{IL} 18=\mathrm{p}$ value $=2.5$ (between both groups IL $18 \mathrm{p}$ value $=6.5$ ) $\}$. ${ }^{\mathrm{g}}$ IgG $\left\{\mathrm{p}\right.$ value $\geq 0.002 ;{ }^{\mathrm{h}} \mathrm{IgG} \mathrm{p}$ value $\geq 0.003$. (between both groups IgG p value $=0.0009\}$.

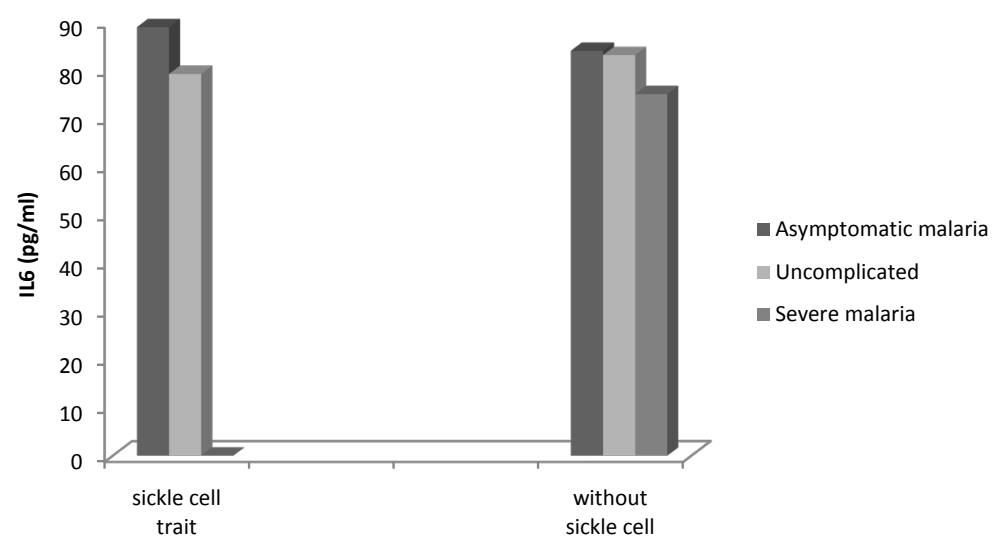

Figure 2. Total IL 6 levels in malarial patients with and without sickle cell trait (IL 6 p value $>0.003$ ).

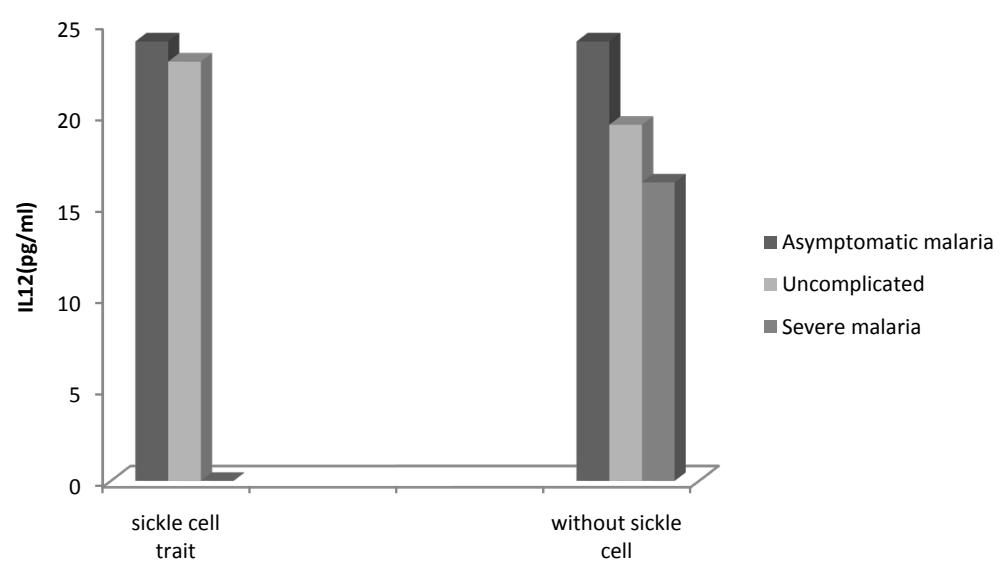

Figure 3. Total IL 12 levels in malarial patients with and without sickle cell trait (IL $12 \mathrm{p}$ value $=0.1$ ) 


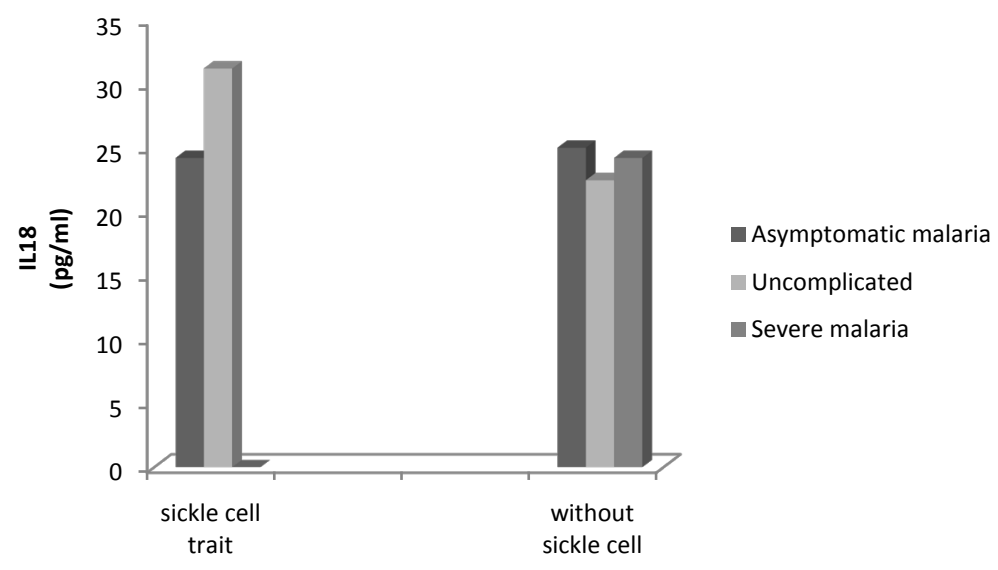

Figure 4. Total IL 18 levels in malarial patients with and without sickle cell trait (IL 18 p value $=6.5$ )

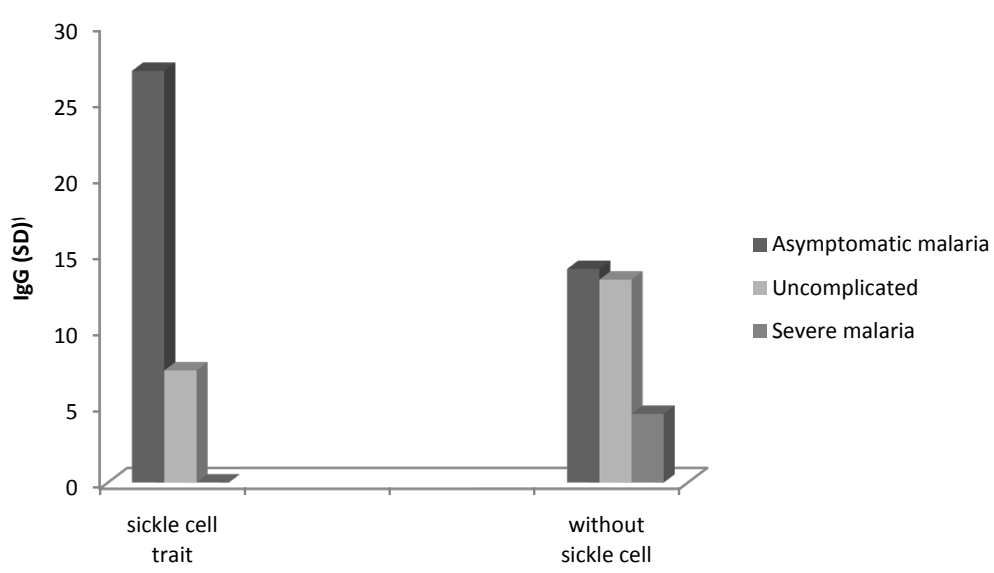

Figure 5. Total IgG levels in malarial patients with and without sickle cell trait $($ IgG p value $=0.0009)$.

$13.3 \pm 10.84$ ) than in patients with uncomplicated clinical malaria with sickle cell trait (medians $7.35 \pm 2.95$ ) while in asymptomatic malaria and severe malaria, medians (27 $27 \pm 11.13$ versus $4.54 .5 \pm 2.75$ ). This differences was statistically highly significant (p value $=0.0009)($ Figure $5 \&$ Table 2$)$.

\section{Discussion}

Malaria remains one of the most important parasitic infections in the world. $P$. falciparum accounts for a vast majority of malaria associated morbidity and mortality. In endemic countries, infection with $P$. falciparum causes a range of outcomes, including asymptomatic parasitaemia, uncomplicated disease and severe malaria, which commonly progresses to death [31].

Sickle cell anemia (SCA), which is caused by having two copies of an abnormal gene (HbS) that causes red cells to deform easily, occurs more frequently in populations exposed to malaria. Malaria resistance by the sickle cell trait has served as the prime example of genetic selection for over half a century. Nevertheless, the mechanism of this resistance remains the subject of considerable debate. It probably involves innate factors such as the reduced ability of Plasmodium falciparum parasites to grow and multiply in HbAS erythrocytes, recent observations suggest that it might also involve the accelerated acquisition of malaria-specific immunity [32].

The immune system plays an important role in inflammatory conditions in sickle cell trait. Several cytokines, such as interleukin-1 beta (IL-1 $\beta$ ) and tumor necrosis factor-alpha (TNF- $\alpha$ ), are associated with the activation of leukocytes, particularly monocytes and neutrophils, in sickle cell trait. The activation of cells and the release of cytokines (IL-18, IL-17, IL-23, IL-12 and IL10) stimulate the TNF (Mansell and Jenkins 2013). IL-1 $\beta$ and IL-18 
are important players in vascular modulation but further analysis is needed to understand the interaction of these cytokines with other cytokines [33].

In our study among malaria patients without sickle cell trait, regarding cytokines and IgG in uncomplicated clinical malaria and severe malaria, significant increase in IL6, IL12 and IgG in uncomplicated malaria was found. Meanwhile, among malaria patients with sickle cell trait, Cytokines (IL6, IL12) and IgG were higher in asymptomatic cases than in uncomplicated clinical malaria, and the differences in IgG was statistically significance while IL18 was higher in uncomplicated malaria than in asymptomatic malaria but difference was not significant. Serum IL6 levels were significantly higher in patients with uncomplicated clinical malaria without sickle cell trait than in patients with uncomplicated clinical malaria with sickle cell trait. Serum IgG levels were higher in patients with uncomplicated clinical malaria without sickle cell trait than in patients with uncomplicated clinical malaria with sickle cell trait while in asymptomatic malaria in patient with Sickle cell trait, the total IgG was very high. This difference was statistically highly significant. Meanwhile IL12 was higher in uncomplicated cases compared to those with severe cases in malaria without sickle cell and the difference was statistically significant and also increased in asymptomatic cases in malaria patient compared to uncomplicated case with sickle cell trait but the difference was statistically insignificant. IL18 was higher in severe cases compared to those with uncomplicated cases in malaria without sickle cell but the difference was statistically insignificant and also increased in uncomplicated cases than asymptomatic malaria patient with sickle cell trait.

The human immune response to $P$. falciparum infection involves the release of cytokines that may contribute to the control of the parasites' replication. These cytokines are also involved in the pathogenesis of the malaria caused by the infection, leading to the appearance of symptoms of varying severity. The asymptomatic sicklers had significantly lower expression of tumor necrosis factor than the non-sicklers with severe malaria, but these two groups showed similar expression of interferon-gamma, interleukin-4 and interleukin-6, IL12, IL18 [34]. Immunity takes over with CD4 + T-cells becoming the main producers of interleukin-12 defines type 1 helper cells and is associated with a strong cell-mediated immunity with production of IL-4, 5, 6, 9 and 10. [35] performed a similar study of HbAS children who were infected with Plasmodium falciparum. Surprisingly, detectable levels of IL-12 were found in patients with mild malaria, but not in asymptomatic individuals.

Interleukin-18 (IL-18) is a proinflammatory cytokine with diverse pleiotropic effects; it is important for regulating innate and acquired immunity in inflammatory and infectious diseases. When we studied the IL18 we did not find any significant differences between the two groups of patients. A previous study investigated the relationship between IL-12 and IL-18 and clinical malaria reported increase of IL-18 in uncomplicated malaria, which progressively declined in moderate malaria, and there was a further decrease in children with severe malaria anemia [36]. These results parallel another study showing significantly elevated IL-12 and IL-18 cases with mild malaria that decreased as disease severity progressed [37]. In contrast, a close association between increased IL-18 levels and severe falciparum malaria has been demonstrated. IL-18 plays an important role in conditioning severe malaria [38]. However, no studies to date have reported the role of polymorphic variants of IL-18 gene in modulating malaria in peripheral blood mononuclear cells or plasma [39].

[40] [41] demonstrated that the mean serum level of IL-6 was higher in sickle cell trait patients than in normal controls, and there was also a significant increase in IL-6 levels in crisis patients when compared to steady-state patients. [42] reported that cytokine levels in SCA patients with periodontal inflammation and found that the SCA group displayed significantly higher levels of various cytokines, including IFN- $\gamma$, than the control group. There was also elevated production ofIL-6 in these patients than in control patients, but this difference did not reach statistical significance in agreement with our study. Surprisingly, IL-6 levels were significantly higher during the steady state than during painful crises. Other investigators report normal or reduced levels of the same proinflammatory cytokines [43].

The mechanism by which HbAS protects against malaria is probably related to the physical characteristics of HbAS erythrocytes, a number of studies suggest that HbAS may also enhance the acquisition of natural immunity [44]; however, establishing this relationship is difficult because immunity to malaria is hard to measure. To date, no single immune response has been described that reliably predicts protective immunity. Our study is, to our knowledge, the first with sufficient power to observe the protective effect of HbAS on the basis of cytokines. We found that HbAS protection increases significantly the levels of IgG, cytokines IL-6 and IL 12 in patients with sickle cell trait than those without sickle cell trait, while it is possible that this observation could result from any factor that both affects malaria risk and varies with age, accelerated immune acquisition seems by far the most likely explanation. So how might HbAS result in the accelerated acquisition of malaria-specific immunity? 
A number of mechanisms have been proposed, in common with other red cell genetic defects, enhanced phagocytosis by monocytes of HbAS red blood cells infected with ring-stage $P$. falciparum was found to be enhanced compared to that of infected HbAA cells, providing evidence for a role of the innate immune system in protection against $P$. falciparum in HbAS individuals. Enhanced phagocytosis may be due to increased presentation of opsonins, including membrane bound IgG, C3c, membrane-bound hemichromes, and aggregated band 3 [45].

As an alternative explanation, it seems possible that by controlling parasite densities during malaria infections [46] innate processes might paradoxically increase the chronicity of individual infections. This hypothesis is supported by the greater number of strains of $P$. falciparum parasites found in HbAS than HbAA children at cross-sectional survey [47]. By increasing the duration of individual malaria infections HbAS might paradoxically increase host exposure to a variety of antigens capable of inducing malaria-specific immunity. In our current study we have focused on, asymptomatic, uncomplicated and severe cases of malaria, $63.3 \%$ of malaria cases were asymptomatic and $36.7 \%$ of cases were uncomplicated while no severe cases was recorded among patients with sickle cell trait. For accelerated malaria-specific immunity to be relevant to HbAS selection it would have to operate within the period of maximum risk for severe and fatal malaria. [48] reported that HbAS is strongly protective against severe and fatal malaria, this may have reflected early protection by maternally transferred immunoglobulins, given the level of protection conferred by HbAS against severe malaria. The relevance of our observations in asymtomatic clinical malaria to the protection afforded by HbAS against severe and fatal malaria therefore remains unknown,while immunity against severe malaria develops significantly more rapidly than immunity to asymtomatic clinical attacks, the determinants of each remain poorly understood. We suggest that establishing the role of HbAS in each of these processes may be one route to learning more about the mechanisms involved.

$P$. falciparum parasites induced sickling of HbAS red blood cells in vitro, by increase in the polymerized hemoglobin or a reduction of intracellular $\mathrm{pH}$ [49] leading to enhanced phagocytosis of infected cells and reduced parasitaemia compared to that in HbAA individuals. Other specific intra-erythrocytic conditions of HbAS red blood cells, such as low intracellular potassium, high concentrations of hemoglobin or osmotic shrinkage of the red blood cell cause an inhospitable environment for parasites [50].

Biochemical and mechanical changes in infected HbAS red blood cells have been shown to alter disease progression. Decreased rosette formation and the resulting decreased circulatory obstruction might contribute to protection against severe malaria in HbAS individuals [51].

In our study we found evidence for an enhanced humeral response in subjects with HbAS. Increased levels of gamma globulin were found in HbAS compared to HbAA patients. However, higher levels of specific antibodies directed at parasite surface antigens believed to play a role in protective responses. Another study found lower levels of IgG1 and IgG3 in HbAS individuals [52], possibly due to reduced exposure to studied antigens in HbAS individuals. In contrast, higher levels of IgG, which are located on the surface of the red blood cell, have been found in individuals with HbAS in a number of studies. On study found HbAS individuals had a higher IgG response to the infected red blood cell. This might be due to enhanced humoral immune response in HbAS individuals may be directed at proteins on the surface of the infected red leading to increased splenic uptake of infected red blood cells in HbAS individuals [53].

In our study among patients with uncomplicated clinical malaria, serum level of IgG in HbSS-malaria subjects in this study was slightly lower than that of HbAA-malaria while among asymptomatic malaria, serum level of IgG were significantly higher in HbSS-malaria subjects than in HbAA-malaria. Other investigators have reported a reduced serum IgG in HbSS-malaria compared with HbAA without malaria [54]. Reduced IgG observed in HbSS-malaria suggests that perhaps at the time of the investigation, the subjects were not harboring clinical doses of infectious agents to trigger over-production of IgG. In response to endothelial cell damage, cytokines such as IL-1, IL-6 and TNF are produced. IL-1 is known to stimulate T and B cells while IL-6 differentiates B cells into antibody forming cells. The reason for a higher level of IgG in HbSS malaria subjects compared with HbAA malaria among asymptomatic individuals could be a result of higher Plasmodium density caused by incomplete clearance of parasite from the blood or may be a result of more sequestration ability of Plasmodium infected sickled RBCs. HbSS + malaria patients had the highest values of the 3 classes of immunoglobulin (IgM, IgA and IgG). Humeral responses to malaria show pronounced increase cytophilic antibodies IgG1 and IgG3 subclasses, unlike responses to other pathogens where IgG2 dominate [55].

The main impetus for trying to understand immunity to malaria is the need to develop effective malaria vaccines. Despite years of knowing that humans can be immune to malaria the mechanisms underlying this immun- 
ity are yet to be properly understood. Incidence among people residing in a malaria endemic area may be attributable to genetic factors [56]-[59].

\section{Conclusion}

Our observations suggest that malaria protection by HbAS involves the enhancement of not only innate but also of acquired immunity to the parasite. A better understanding of the underlying mechanisms might yield important insights into both these processes. There was obvious increase in the total IgG, IL 6 in malaria patients with sickle cell trait and in a symptomatic and uncomplicated case compared to malaria patients without sickle cell trait and in severe cases of malaria. Meanwhile IL12 was higher in uncomplicated cases compared to those with severe cases in malaria without sickle cell and also increased in asymptomatic cases in malaria patient with sickle cell trait compared to uncomplicated cases. As regard to IL 18 it was raised in malaria patients with sickle cell trait. The presence of HbAS is associated with increased acquired immunity to mild malaria. Further work will need to be done to work out how this change in immunity occurs. It is not yet known whether these results are also true for protection against severe malaria, and in any case the protection is only partial; hence, treatment of anyone with malaria, whatever their sickle cell status, is essential.

\section{References}

[1] World Health Organization (1994, 1997) World Malaria Situation in 1994, 1997. Weekly Epidermal Reek, $72,269$.

[2] Embury, S.H., Hebbel, R.P., Mohandes, N. and Steinberg, M.H. (Eds.) (1994) Sickle Cell Disease: Basic Principals and Clinical Practice. Raven Press, New York.

[3] Hedrick, P.W. (2011) Population Genetics of Malaria Resistance in Humans. Heredity, 107, 283-230.

[4] Holder, A.A. (1999) Malaria Vaccines. Proceedings of the National Academy of Sciences of the United States of America, 96, 1167-1169. http://dx.doi.org/10.1073/pnas.96.4.1167

[5] Crutcher, J.M., Stevenson, M.M. and Hoffman, S.L. (1995) Interleukin 12 and Malaria. Research in Immunology, 146, 552-559. http://dx.doi.org/10.1016/0923-2494(96)83031-8

[6] Doolan, D.L., Beck, H.P. and Good, M.F. (1994) Evidence for Limited Activation of Distinct CD4+ T Cells Subsets in Response to the Plasmodium falciparum Circumsporozoite Protein in Papua New Guinea. Parasite Immunology, 16, 129-136. http://dx.doi.org/10.1111/j.1365-3024.1994.tb00332.x

[7] Goodier, M.R. and Targett, G.A. (1997) Polyclonal T-Cell Responses to Plasmodium falciparum Gametocytes in Malaria Nonexposed Donors. Parasite Immunology, 19, 419-425. http://dx.doi.org/10.1046/j.1365-3024.1997.d01-238.x

[8] Malaguarnera, L. and Musumeci, S. (2002) The Immune Response to Plasmodium falciparum Malaria. The Lancet Infectious Diseases, 2, 472-478. http://dx.doi.org/10.1016/S1473-3099(02)00344-4

[9] Richards, A.L. (1997) Tumour Necrosis Factor and Associated Cytokines in the Host’s Response to Malaria. International Journal for Parasitology, 27, 1251-1263. http://dx.doi.org/10.1016/S0020-7519(97)00122-7

[10] Luty, A.J., Lell, B., Schmidt-Ott, R., et al. (1999) Interferon-Gamma Responses Are Associated with Resistance to Reinfection with Plasmodium falciparum in Young African Children. The Journal of Infectious Diseases, 179, 980-988. http://dx.doi.org/10.1086/314689

[11] Dinarello, C.A. (1999) Interleukin-18. Methods, 19, 121-132. http://dx.doi.org/10.1006/meth.1999.0837

[12] Yoshimoto, T., Takeda, K., Tanaka, T., Ohkusu, K., Kashiwamura, S., Okamura, H., et al. (1998) IL-12 Up-Regulates IL-18 Receptor Expression on T Cells, Th1 Cells and B Cells: Synergism with IL-18 for IFN-Gamma Production. Journal of Immunology, 161, 3400-3407.

[13] Kaser, A., Kaser, S., Kaneider, N.C., Enrich, B., Wiedermann, C.J. and Tilg, H. (2004) Interleukin-18 Attracts Plasmacytoid Dendritic Cells (DC2s) and Promotes Th1 Induction by DC2s through IL-18 Receptor Expression. Blood, 103, 648-655. http://dx.doi.org/10.1182/blood-2002-07-2322

[14] Hensmann, M. and Kwiatkowski, D. (2001) Cellular Basis for Early Cytokine Response to Plasmodium falciparum. Infection and Immunity, 69, 2364-2371. http://dx.doi.org/10.1128/IAI.69.4.2364-2371.2001

[15] Torre, D. (2009) Early Production of $\gamma$-Interferon in Clinical Malaria: Role of Interleukin-18 and Interleukin-12. Clinical Infectious Diseases, 48, 1481-1482.

[16] Weatherall, D.J. (1987) Common Genetic Disorders of the Red Cell and the "Malaria Hypothesis". Annals of Tropical Medicine and Parasitology, 81, 539-548.

[17] Aidoo, M., Terlouw, D.J., Kolczak, M.S., McElroy, P.D., ter Kuile, F.O., et al. (2002) Protective Effects of the Sickle Cell Gene against Malaria Morbidity and Mortality. The Lancet, 359, 1311-1312. 
http://dx.doi.org/10.1016/S0140-6736(02)08273-9

[18] Sokhna, C.S., Rogier, C., Dieye, A. and Trape, J.F. (2000) Host Factors Affecting the Delay of Reappearance of Plasmodium falciparum after Radical Treatment among a Semi-Immune Population Exposed to Intense Perennial Transmission. The American Journal of Tropical Medicine and Hygiene, 62, 266-270.

[19] Abu-Zeid, Y.A., Abdulhadi, N.H. and Hviid, L. (1991) Lymphoproliferative Responses to Plasmodium falciparum Antigens in Children with and without the Sickle Cell Trait. Scandinavian Journal of Immunology, 34, 237-242. http://dx.doi.org/10.1111/j.1365-3083.1991.tb01542.x

[20] Abu-Zeid, Y.A., Abdulhadi, N.H. and Theander, T.G. (1992) Seasonal Changes in Cell Mediated Immune Responses to Soluble Plasmodium falciparum Antigens in Children with Haemoglobin AA and Haemoglobin AS. Transactions of the Royal Society of Tropical Medicine and Hygiene, 86, 20-22. http://dx.doi.org/10.1016/0035-9203(92)90422-9

[21] Abu-Zeid, Y.A., Theander, T.G. and Abdulhadi, N.H. (1992) Modulation of the Cellular Immune Response during Plasmodium falciparum Infections in Sickle Cell Trait Individuals. Clinical Experimental Immunology, 88, 112-118. http://dx.doi.org/10.1111/j.1365-2249.1992.tb03048.x

[22] Miller, L.H., Good, M.F. and Milon, G. (1994) Malaria Pathogenesis (Review). Science, 264, 1878-1883. http://dx.doi.org/10.1126/science.8009217

[23] Chattopadhyay, R., Sharma, A. and Srivastava, V.K. (2003) Plasmodium falciparum Infection Elicits Both VariantSpecific and Cross-Reactive Antibodies against Variant Surface Antigens. Infection and Immunity, 71, 597-604. http://dx.doi.org/10.1128/IAI.71.2.597-604.2003

[24] Tjitra, E., Suprianto, S., Dyer, M., Curie, J. and Anstey, N. (1999) Field Evaluation of the ICT Malaria P.f/P.v Immunochromatographic Test for Detection of Plasmodium falciparum and Plasmodium vivax in Patients with a Presumptive Clinical Diagnosis of Malaria in Eastern Indonesia. Journal of Clinical Microbiology, 37, 2412-2417.

[25] Moody, A. (2002) Rapid Diagnostic Tests for Malaria Parasites. Clinical Microbiology Reviews, 15, 66-78. http://dx.doi.org/10.1128/CMR.15.1.66-78.2002

[26] Williams, T.N., Mwangi, T.W., Wambua, S., Alexander, N.D., Kortok, M., Snow, R.W. and Marsh, K. (2005) Sickle Cell Trait and the Risk of Plasmodium falciparum Malaria and Other Childhood Diseases. The Journal of Infectious Diseases, 192, 178-186.

[27] Bowman, J.E. and Murray Jr., R.F. (1990) Genetic Variation and Disorders in Peoples of African Origin. Johns Hopkins University Press, Baltimore, 196-201.

[28] Jallow, M., Teo, Y.Y., Small, K.S., Rockett, K.A., Deloukas, P., Clark, T.G., Kivinen, K., Bojang, K.A., Conway, D.J., Pinder, M., Sirugo, G., Sisay-Joof, F., Usen, S., Auburn, S., Bumpstead, S.J., Campino, S., Coffey, A., Dunham, A., Fry, A.E., Green, A., Gwilliam, R., Hunt, S.E., Inouye, M., Jeffreys, A.E., Mendy, A., Palotie, A., Potter, S., Ragoussis, J., Rogers, J., Rowlands, K., et al. (2009) Genome-Wide and Fine-Resolution Association Analysis of Malaria in West Africa. Nature Genetics, 12, 657-665. http://dx.doi.org/10.1038/ng.388

[29] Williams, T.N., Mwangi, T.W., Roberts, D.J., Alexander, N.D., Weatherall, D.J., Wambua, S., Kortok, M., Snow, R.W. and Marsh, K. (2005) An Immune Basis for Malaria Protection by the Sickle Cell Trait. PLoS Medicine, 2, e128. http://dx.doi.org/10.1371/journal.pmed.0020128

[30] Pass, K.A., Lane, P.A. and Fernhoff, P.M. (2000) US Newborn Screening System Guidelines II: Follow up of Children, Diagnosis, Management and Evaluation. Journal of Pediatrics, 37, S1-S46. http://dx.doi.org/10.1067/mpd.2000.109437

[31] Hassan, D.A., Marques, C., Santos-Gomes, G.M., do Rosario, V.E., Mohamed, H.S., Elhussein, A.M., Ibrahim, M.E. and Abdulhadi, N.H. (2009) Differential Expression of Cytokine Genes among Sickle-Cell-Trait (HbAS) and Normal (HbAA) Children Infected with Plasmodium falciparum. Annals of Tropical Medicine \& Parasitology, 103, $283-295$. http://dx.doi.org/10.1179/136485909X435049

[32] Hussain, M.J., Forrester, T. and Greenough, A. (2012) Cytokine Levels and Profiles in Children Related to Sicklecell Disease and Asthma Status. Journal of Interferon \& Cytokine Research, 32, 1-5. http://dx.doi.org/10.1089/jir.2011.0030

[33] Horowitz, A., Newman, K.C., Evans, J.H., Korbel, D.S., Davis, D.M. and Riley, E.M. (2010) Cross-Talk between T Cells and NK Cells Generates Rapid Effector Responses to Plasmodium falciparum-Infected Erythrocytes. The Journal of Immunology, 184, 6043-6052. http://dx.doi.org/10.4049/jimmunol.1000106

[34] Musa, B.O., Onyemelukwe, G.C., Hambolu, J.O., Mamman, A.I. and Isa, A.H. (2010) Pattern of Serum Cytokine Expression and T-Cell Subsets in Sickle Cell Disease Patients in Vaso-Occlusive Crisis. Clinical and Vaccine Immunology, 17, 602-608. http://dx.doi.org/10.1128/CVI.00145-09

[35] Luzina, I.G., Keegan, A.D., Heller, N.M., Rook, G.A., Shea-Donohue, T. and Atamas, S.P. (2012) Regulation of Inflammation by Interleukin-4: A Review of “Alternatives”. Journal of Leukocyte Biology, 92, 753-764. http://dx.doi.org/10.1189/jlb.0412214 
[36] Mansell, A. and Jenkins, B.J. (2013) Dangerous Liaisons between Interleukin-6 Cytokine and Toll-Like Receptor Families: A Potent Combination in Inflammation and Cancer. Cytokine \& Growth Factor Reviews, 24, 249-256. http://dx.doi.org/10.1016/j.cytogfr.2013.03.007

[37] Hibbert, J.M., Hsu, L.L., Bhathena, S.J., Irune, I., Sarfo, B., Creary, M.S., Gee, B.E., Mohamed, A.I., Buchanan, I.D., Al-Mahmoud, A. and Stiles, J.K. (2005) Proinflammatory Cytokines and the Hypermetabolism of Children with Sickle Cell Disease. Experimental Biology and Medicine, 230, 68-74.

[38] Veiga, P.C., Schroth, R.J., Guedes, R., Freire, S.M. and Williams, T.N., Mwangi, T.W., Roberts, D.J., Alexander, N.D., Weatherall, D.J., Wambua, S., Kortok, M., Snow, R.W. and Marsh, K. (2005) An Immune Basis for Malaria Protection by the Sickle Cell Trait. PLoS Medicine, 2, e128. http://dx.doi.org/10.1371/journal.pmed.0020128

[39] Polley, S.D., Mwangi, T., Kocken, C.H., Thomas, A.W., Dutta, S., et al. (2004) Human Antibodies to Recombinant Protein Constructs of Plasmodium falciparum Apical Membrane Antigen 1 (AMA1) and Their Associations with Protection from Malaria. Vaccine, 23, 718-728. http://dx.doi.org/10.1016/j.vaccine.2004.05.031

[40] Ayi, K., Turrini, F., Piga, A. and Arese, P. (2004) Enhanced Phagocytosis of Ring-Parasitized Mutant Erythrocytes. A Common Mechanism That May Explain Protection against Falciparum-Malaria in Sickle-Trait and Beta-Thalassemia-Trait. Blood, 104, 3364-3371. http://dx.doi.org/10.1182/blood-2003-11-3820

[41] Roberts, D.J. and Williams, T.N. (2003) Haemoglobinopathies and Resistance to Malaria. Redox Report, 8, $294-300$. http://dx.doi.org/10.1179/135100003225002998

[42] Ntoumi, F., Mercereau-Puijalon, O., Ossari, S., Luty, A., Reltien, J., et al. (1997) Plasmodium falciparum Sickle-Cell Trait is Associated with Higher Prevalence of Multiple Infections in Gabonese Children with Asymptomatic Infections. Experimental Parasitology, 87, 39-46. http://dx.doi.org/10.1006/expr.1997.4173

[43] Roth Jr, E.F., Friedman, M., Ueda, Y., Tellez, I., Trager, W. and Nagel, R.L. (1978) Sickling Rates of Human AS Red Cells Infected in Vitro with Plasmodium falciparum Malaria. Science, 12, 650-652. http://dx.doi.org/10.1126/science.360396

[44] Mackinnon, M.J., Mwangi, T.W., Snow, R.W., Marsh, K. and Williams, T.N. (2005) Heritability of Malaria in Africa. PLoS Medicine, 2, e340. http://dx.doi.org/10.1371/journal.pmed.0020340

[45] Cholera, R., Brittain, N.J., Gillrie, M.R., Lopera-Mesa, T.M., Diakité, S.A.S., Arie, T., Krause, M.A., Guindo, A., Tubman, A., Fujioka, H., Diallo, D.A., Doumbo, O.K., Ho, M., Wellems, T.E. and Fairhurst, R.M. (2008) Impaired Cytoadherence of Plasmodium falciparum-Infected Erythrocytes Containing Sickle Hemoglobin. Proceedings of the National Academy of Sciences of the United States of America, 12, 991-996. http://dx.doi.org/10.1073/pnas.0711401105

[46] Sarr, J.B., Pelleau, S., Toly, C., Guitard, J., Konaté, L., Deloron, P., Garcia, A. and Migot-Nabias, F. (2006) Impact of Red Blood Cell Polymorphisms on the Antibody Response to Plasmodium falciparum in Senegal. Microbes and Infection, 12, 1260-1268. http://dx.doi.org/10.1016/j.micinf.2005.12.005

[47] Diatta, A.-M., Marrama, L., Tall, A., Trape, J.-F., Dieye, A., Garraud, O., Mercereau-Puijalon, O. and Perraut, R. (2004) Relationship of Binding of Immunoglobulin G to Plasmodium falciparum-Infected Erythrocytes with Parasite Endemicity and Antibody Responses to Conserved Antigen in Immune Individuals. Clinical and Diagnostic Laboratory Immunology, 12, 6-11.

[48] Yeo, T.W., Yeo, D.A., Lampah, R., Gitawati, E., Tjitra, E., Kenangalem, Y.R., McNeil, C.J., Darcy, D.L., Granger, J.B. and Weinberg, B.K. (2007) An Antioxidant Link between Sickle Cell Disease and Severe Malaria. The Journal of Experimental Medicine, 204, 2693-2704. http://dx.doi.org/10.1084/jem.20070819

[49] Frenette, P.S. (2002) Sickle Cell Vaso-Occlusion: Multistep and Multicellular Paradigm. Current Opinion Hematology, 9, 101-106. http://dx.doi.org/10.1097/00062752-200203000-00003

[50] LaMonte, G., Philip, N., Reardon, J., Lacsina, J.R., Majoros, W., Chapman, L., Thornburg, C.D., Telen, M.J., Ohler, U., Nicchitta, C.V., Haystead, T. and Chi, J.-T. (2010) Translocation of Sickle Cell Erythrocyte microRNAs into Plasmodium falciparum Inhibits Parasite Translation and Contributes to Malaria Resistance. Cell Host \& Microbe, 12, 187199.

[51] Nogueira-Filho, G. (2013) Serum Cytokine Profile among Brazilian Children of African Descent with Periodontal Inflammation and Sickle Cell Anaemia. Archives of Oral Biology, 58, 505-510. http://dx.doi.org/10.1016/j.archoralbio.2012.11.006

[52] Lopez, C., Saravia, C., Gomez, A., Hoebeke, J. and Patarroyo, M.A. (2010) Mechanisms of Genetically-Based Resistance to Malaria. Gene, 467, 1-12. http://dx.doi.org/10.1016/j.gene.2010.07.008

[53] Bejon, P., Warimwe, G., Mackintosh, C.L., Mackinnon, M.J., Kinyanjui, S.M., Musyoki, J.N., Bull, P. and Marsh, K. (2009) Immunity to Febrile Malaria in Children: An Analysis That Distinguishes Immunity from Lack of Exposure. Infection and Immunity, 77, 1917-1923. http://dx.doi.org/10.1128/IAI.01358-08

[54] Cabrera, G., Cot, M., Migot-Nabias, F., Kremsner, P.G., Deloron, P. and Luty, A.J.F. (2005) The Sickle Cell Trait Is 
Associated with Enhanced Immunoglobulin G Antibody Responses to Plasmodium falciparum Variant Surface Antigens. The Journal of Infectious Diseases, 191, 1631-1638. http://dx.doi.org/10.1086/429832

[55] Recker, M., Buckee, C.O., Serazin, A., Kyes, S., Pinches, R., Christodoulou, Z., Springer, A.L., Gupta, S. and Newbold, C.I. (2011) Antigenic Variation in Plasmodium falciparum Malaria Involves a Highly Structured Switching Pattern. PLoS Pathogens, 7, e1001306. http://dx.doi.org/10.1371/journal.ppat.1001306

[56] World Health Organization (2006) Fifty-Ninth World Health Assembly A59/9 Provisional Agenda Item 11.4. 24 April 2006.

[57] Berretta, F., St-Pierre, J., Piccirillo, C.A. and Stevenson, M.M. (2011) IL-2 Contributes to Maintaining a Balance between $\mathrm{CD}^{+}{ }^{+} \mathrm{Foxp}^{+}$Regulatory T Cells and Effector $\mathrm{CD} 4^{+} \mathrm{T}$ Cells Required for Immune Control of Blood-Stage Malaria Infection. The Journal of Immunology, 186, 4862-4871.

[58] Clark, T.G., Fry, A.E., Auburn, S., Campino, S., Diakite, M., Green, A., Richardson, A., Teo, Y.Y., Small, K., Wilson, J., Jallow, M., Sisay-Joof, F., Pinder, M., Sabeti, P., Kwiatkowski, D.P. and Rockett, K.A. (2009) Allelic Heterogeneity of G6PD Deficiency in West Africa and Severe Malaria Susceptibility. European Journal of Human Genetics, 17, 1080-1085. http://dx.doi.org/10.1038/ejhg.2009.8

[59] Reiling, L., Richards, J.S., Fowkes, F.J., Barry, A.E., Triglia, T., Chokejindachai, W., Michon, P., Tavul, L., Siba, P.M., Cowman, A.F., Mueller, I. and Beeson, J.G. (2010) Evidence That the Erythrocyte Invasion Ligand PfRh2 Is a Target of Protective Immunity against Plasmodium falciparum Malaria. The Journal of Immunology, 185, 6157-6167. http://dx.doi.org/10.4049/jimmunol.1001555 
Scientific Research Publishing (SCIRP) is one of the largest Open Access journal publishers. It is currently publishing more than 200 open access, online, peer-reviewed journals covering a wide range of academic disciplines. SCIRP serves the worldwide academic communities and contributes to the progress and application of science with its publication.

Other selected journals from SCIRP are listed as below. Submit your manuscript to us via either submit@scirp.org or Online Submission Portal.
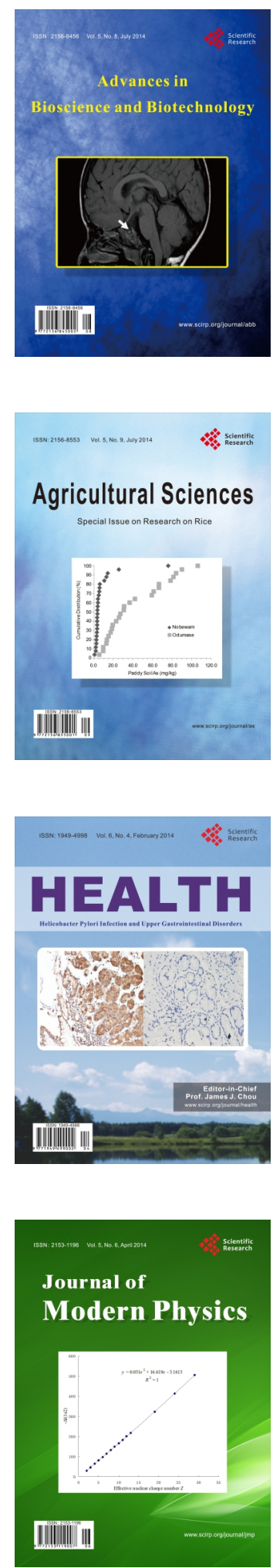
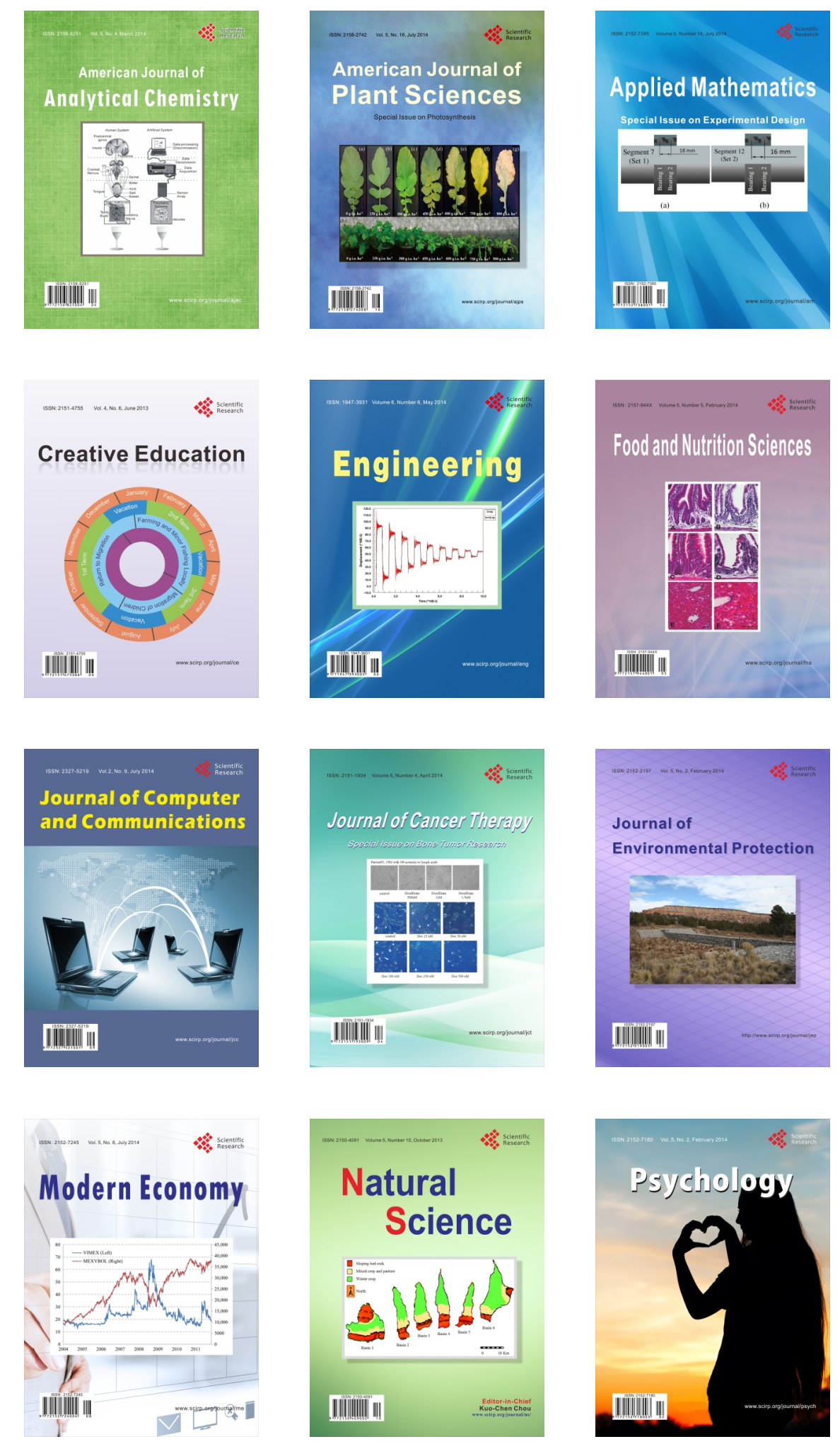